\title{
Enhanced microbial utilisation of dissolved amino acids indicates rapid modification of organic matter in the benthic boundary layer
}

\author{
Will Ritzrau ${ }^{1, *}$, Laurenz Thomsen $^{2}$, Rubén J. Lara ${ }^{3}$, Gerhard Graf ${ }^{4}$ \\ ${ }^{1}$ Sonderforschungsbereich 313, Heinrich-Hecht-Platz 10, D-24118 Kiel, Germany \\ ${ }^{2}$ GEOMAR, Wischhofstr. 1-3, D-24148 Kiel, Germany \\ ${ }^{3}$ Zentrum für Marine Tropenökologie, Klagenfurter Str. 1, D-28359 Bremen, Germany \\ ${ }^{4}$ Universität Rostock, Freiligrathstr. 7/8, D-18055 Rostock, Germany
}

\begin{abstract}
Recent information on activity, abundance, and size of bacteria as well as concentration and composition of particles in the benthic boundary layer (BBL, range of water depths 191 to $479 \mathrm{~m}$ ) was compared to the distribution of these parameters in 2 layers of the water column, the chlorophyll maximum layer (range of water depths 13 to $25 \mathrm{~m}$ ) and the intermediate water depth (IWC, range of water depths 136 to $486 \mathrm{~m}$ ). Microbial activities and concentrations of various biochemical parameters displayed distinct variation patterns in the $\mathrm{BBL}$, exhibiting higher values compared to their variations in the chlorophyll maximum layer and the IWC. In the BBL the microbial utilisation of ${ }^{14} \mathrm{C}$-amino acids revealed no correlation with concentrations of particulate organic carbon (POC), but was related to chlorophyll a ( $\mathrm{chl} \mathrm{a}$ ) equivalents and the ratio of POC and chl a equivalents. The distribution of dissolved free amino acids (DFAA) suggests that not necessarily the concentration but alternatively the accessibility (concentration and transport rate) of DFAA to bacteria determines heterotrophic activity. Results indicate that the BBL represents a distinct environment with rapid modification of organic matter prior to its final incorporation into the sediment.
\end{abstract}

KEY WORDS: Benthic boundary layer $\cdot$ Microbial activity $\cdot$ Polynya

\section{INTRODUCTION}

Microorganisms play a key role in modifying and decomposing dissolved (Kirchman et al. 1991, Amon \& Benner 1994), suspended and sinking particulate organic material (Karl et al. 1984, Smith et al. 1992, Alldredge et al. 1993, Karl \& Tilbrook 1994) in marine ecosystems. Extensive information on the distribution of microorganisms and microbial processes in the upper water column (e.g. Cho \& Azam 1990), the ocean's interior (e.g. Cho \& Azam 1988, Karl et al. 1988) and in the sediments (e.g. Deming \& Yager 1992) is available. However, little is known about the modification of particles and organic matter within the layers close to the sediment-water interface, so far due to sampling problems.

\footnotetext{
•E-mail: will@sfb313.uni-kiel.de
}

In particle-rich environments, like the benthic boundary layer (BBL) (Thomsen et al. 1994), the importance of particle attached bacteria for the transformation of dissolved organic nutrients is highly increased (Palumbo et al. 1984, Iriberri et al. 1987). Flume experiments (Wainright 1987) and field data (Ritzrau \& Graf 1992) revealed that resuspension of surface sediments increases bacterial abundances and biomass in the near-bed water mass. Whether this increase is due to resuspension of larger benthic bacteria or to stimulation of bacterial growth is not known. The latter is supported by recent laboratory and field experiments in which fluid motion or the hydrodynamic regime has been shown to stimulate microbial activity (Confer \& Logan 1991, Logan \& Kirchman 1991, Ritzrau 1996).

We hypothesise that the modification of organic matter close to the seafloor can be as rapid as in the euphotic zone, the primary source area of labile 
marine organic carbon. Samples for the investigation of various particle parameters and rate measurements throughout the water column were collected in the Northeast Water Polynya (NEWP), a polar region of various primary production and hence sedimentation regimes (combining pelagic production in oligotrophic open water, ice edge blooms and low productivity under permanent ice cover). We show that in the NEWP, the BBL represents a distinct environment, with small-scale variations in the vertical distribution of particle composition and enhanced microbial activity which indicate rapid modification and turnover of organic matter prior to its final burial in the sediment.

\section{MATERIALS AND METHODS}

The NEWP is the largest and northernmost summer polynya in the Arctic $\left(77^{\circ}\right.$ to $82^{\circ} \mathrm{N}, 10^{\circ}$ to $15^{\circ} \mathrm{W}$ NEWATER-Investigators 1993). Heterotrophic microbial activity and related chemical parameters were studied in the NEWP in 1992 and 1993 during USCGC 'Polar Sea' and RV 'Polarstern' cruises. A total of 27 stations were sampled (Ritzrau 1997, Ritzrau \& Thomsen 1997), including 15 deployments of a bottom water sampler in 1993 (BWS; Thomsen et al. 1994). For detailed station list see Table 1. Parameters included total suspended matter, particulate organic carbon (POC), chlorophyll a ( $\mathrm{chl}$ a) equivalents as tracer for phytogenic material, bacterial abundance and size distribution and microbial activity, and were determined in various water depths including the chlorophyll maximum layer and the intermediate water column (IWC) down to $2 \mathrm{~m}$ above the bottom, and the BBL. Samples from the chlorophyll maximum layer were taken from the polar influenced, sub-zero surface water layer that covered the entire polynya area from the surface to a depth of 150 to $220 \mathrm{~m}$. Most of the deep water samples (IWC and BBL; maximal water depth $486 \mathrm{~m}$ ) were recovered from stations influenced by warmer Atlantic waters that fill a circular trough system on the north east Greenland shelf (NEWATER-Investigators 1993).

Water samples from the chlorophyll maximum layer and the IWC were collected using $10 \mathrm{I} \mathrm{GOFLO}^{\circ}$ water samplers mounted to a CTD rosette. The BBL was sampled with the BWS, which collects water samples at 4 distinct heights, in this case 40,20,12, and $7 \mathrm{~cm}$ above the seafloor. Additionally the BWS included 3 thermistor probes, a transmissometer, and a compass with current vane observed by a video system. Based on video recordings, the water sampling was triggered from the deck unit of the BWS about 5 min after touch down, allowing resuspended surface sediments to be flushed away by bottom currents. The ability of the BWS to sample 4 distinct horizons above the seafloor was veri- fied in flume experiments and from measurements of oxygen gradients in shallow water environments (for details see Thomsen et al. 1994). The near bottom current velocities at the sampled stations ranged between 1.0 and $26.0 \mathrm{~cm} \mathrm{~s}^{-1}$ at $39 \mathrm{~cm}$ above the seafloor.

To analyse total suspended matter (seston), POC and particulate organic nitrogen (PON), 1.0 to 2.0 l samples were filtered on board ship onto precombusted preweighed Whatman GF/F glass fibre filters and frozen for later analysis. Prior to analysis (Perkin Elmer $240 \mathrm{C}$ CHN-elemental analyser), inorganic carbon. was eliminated by $\mathrm{HCl}$-vapour treatment for $24 \mathrm{~h}$.

Concentrations of phytoplankton derived pigments, i.e. the sum of chl a and phaeopigments, hereafter defined as chl a equivalents, were determined fluorometrically and calculated according to Lorenzen (1967). For the determination of bacterial abundance, $100 \mathrm{ml}$ samples were preserved with formaldehyde at a final concentration of $2 \%$. Bacteria were enumerated and sized by epifluorescence microscopy (Porter \& Feig 1980, Thomsen 1991). The imaging system was calibrated with 1 and $2 \mu \mathrm{m}$ latex beads. Heterotrophic microbial activity was assessed by measuring utilisation rate (sum of incorporation and respiration) of ${ }^{14} \mathrm{C}$ labelled amino acids. $0.1 \mu \mathrm{Ci}$ of a mixture of 15 naturally occurring amino acids $\left(\mathrm{L}\left[{ }^{14} \mathrm{C}(\mathrm{U})\right]\right.$ amino acids DuPont NEN Research, NEC 445e, specific activity $263 \mathrm{mCi} \mathrm{mmol}^{-1}$ amino acids) was added to replicate $20 \mathrm{ml}$ water samples. Final substrate concentration in the serum bottles was $2.4 \mathrm{ng}{ }^{14} \mathrm{C}$-amino acids $\mathrm{ml}^{-1}$ sample. Samples were incubated in time course experiments for 16 to $24 \mathrm{~h}$ in constant temperature baths $\left(1.0,0.0\right.$ or $\left.-1.3^{\circ} \mathrm{C}\right)$ close to in situ temperature. Respiration was measured by trapping ${ }^{14} \mathrm{CO}_{2}$ in wicks soaked with phenylethylamine. After incubation, whole samples were filtered sequentially through 3.0 and $0.2 \mu \mathrm{m}$ pore size cellulose acetate filters. The activity in wicks and on filters was assayed by scintillation counting (Hobbie \& Crawford 1969). The total incorporation rate is the sum of activity retained on the 3.0 and $0.2 \mu \mathrm{m}$ filters. Cell-specific activity was calculated by dividing the measured ${ }^{14} \mathrm{C}$-amino acid utilisation rate by the bacterial abundance of the sample, assuming various active fractions of the microbial community (see text below). The technique for analysis of dissolved free amino acids (DFAA) is based, with minor modification, on the OPA method (ophthaldialdehyde derivatisation) according to Lindroth \& Mopper (1979). The relative error for the determination of total DFAA at the reported concentrations was about $\pm 5 \%$.

For analyses of the various data sets, non-parametric statistics were used according to Sokal \& Rohlf (1981). The Mann-Whitney $U$-test was used to test the similarity of the data sets between 2 layers, e.g. IWC and the 
BBL. Kendall's $\tau$ test was applied for various correlation analyses. No significant differences between IWC samples from 1992 and 1993 were detected for concentrations of $\mathrm{POC}$, utilisation of ${ }^{14} \mathrm{C}$-amino acids and bacterial abundances (Mann-Whitney $U$-test, $\mathrm{p} \geq 0.05$ ). Thus these samples were pooled for statistical analyses between the BBL and the IWC. In cases with significant differences between 1992 and 1993 only IWC and BBL samples from 1993 were included in the statistical analyses.

\section{RESULTS AND DISCUSSION}

The vertical distributions (Fig. 1) of the various parameters in the water column of the NEWP resembled typical profiles from other oceanic areas, e.g. for Pacific waters reported by Craven \& Carlucci (1989): high concentrations and activities in surface waters and subsequently decreasing values in the intermediate water column (IWC) with a slight increase at $2 \mathrm{~m}$ above the seafloor, with significantly different values among the 3 water layers (Fig. 1). Concentrations of POC and chl a equivalents decreased from the surface waters $\left(58.0\right.$ to 278.2 and 0.23 to $4.08 \mu \mathrm{g} \mathrm{l}^{-1}$, respectively) down to the IWC (10.3 to 102.5 and $<0.01$ to $0.57 \mathrm{Hg} \mathrm{l}^{-1}$, respectively) by factors of 4.1 and 32 to 95 , respectively (Table 1 ). The median value of microbial community utilisation of ${ }^{14} \mathrm{C}$-amino acids in the chlorophyll maximum layer was $>10$ times higher compared to that in the IWC.
Considering all samples from below the euphotic zone the particle composition in terms of absolute concentrations of POC and chl a equivalents as well as microbial activities differed significantly between the IWC and the BBL. Concentrations of POC were significantly higher (Mann-Whitney $U$-test; $\mathrm{p} \leq 0.0001, \mathrm{n}=$ 104, including data from 1992 and 1993) in the BBL compared to the IWC (Table 1). Although the concentrations of chl a equivalents in the IWC differed between 1992 and 1993, the overall trend of higher values in the BBL than in the IWC (Fig. 1) was statistically supported for 1993 (Mann-Whitney $U$-test; $\mathrm{p} \leq 0.0017, \mathrm{n}=89$ ). However, the ratio of POC to chl a equivalents, which is a qualitative tracer for the 'freshness' of the organic matter, did not differ significantly between the BBL and the IWC (Mann-Whitney $U$-test; $\mathrm{p}>0.53, \mathrm{n}=81$ ). The utilisation of ${ }^{14} \mathrm{C}$-amino acids by the microbial community in the BBL was also significantly higher than in the IWC (Mann-Whitney $U$-test; $\mathrm{p} \leq 0.0001, \mathrm{n}=111$ ). This pattern of high ${ }^{14} \mathrm{C}$-amino acids utilisation in the BBL and lower rates in the IWC was also observed in bacterial protein production (BPP) based on ${ }^{3} \mathrm{H}$-leucine incorporation and total bacterial production based on ${ }^{3} \mathrm{H}$-thymidine incorporation (P. K. Bjørnsen pers. comm.).

The importance of the BBL for microbial processes becomes obvious when one investigates the metabolic activity of individual cells within a community, though this is not well described by the applied approach of measuring bulk amino acid utilisation. Although microbial abundances were higher in the surface layer
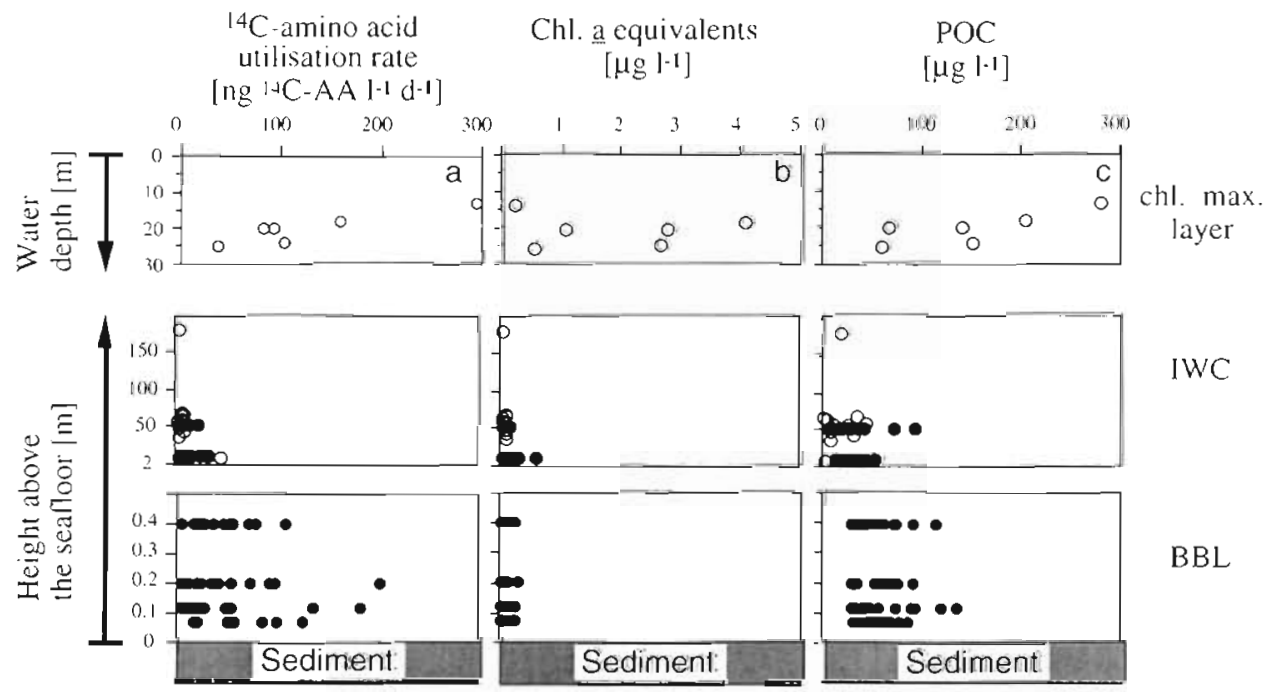

IWC

$\mathrm{BBL}$

Fig. 1. Distribution of (a) ${ }^{14} \mathrm{C}$-amino acid (AA) utilisation, (b) chlorophyll a equivalents and (c) particulate organic carbon (POC) in the water column in $1992(0)$ and 1993 (•) during the NEWP 92 and ARK IX cruises. Data from the benthic boundary layer (BBL) and the intermediate water column (IWC) are presented with reference to the seafloor (plotted as height above bottom). Samples from the chlorophyll maximum layer are arranged according to water depth from the sea surface. For detailed description of the station list and sampling time see Table 1 


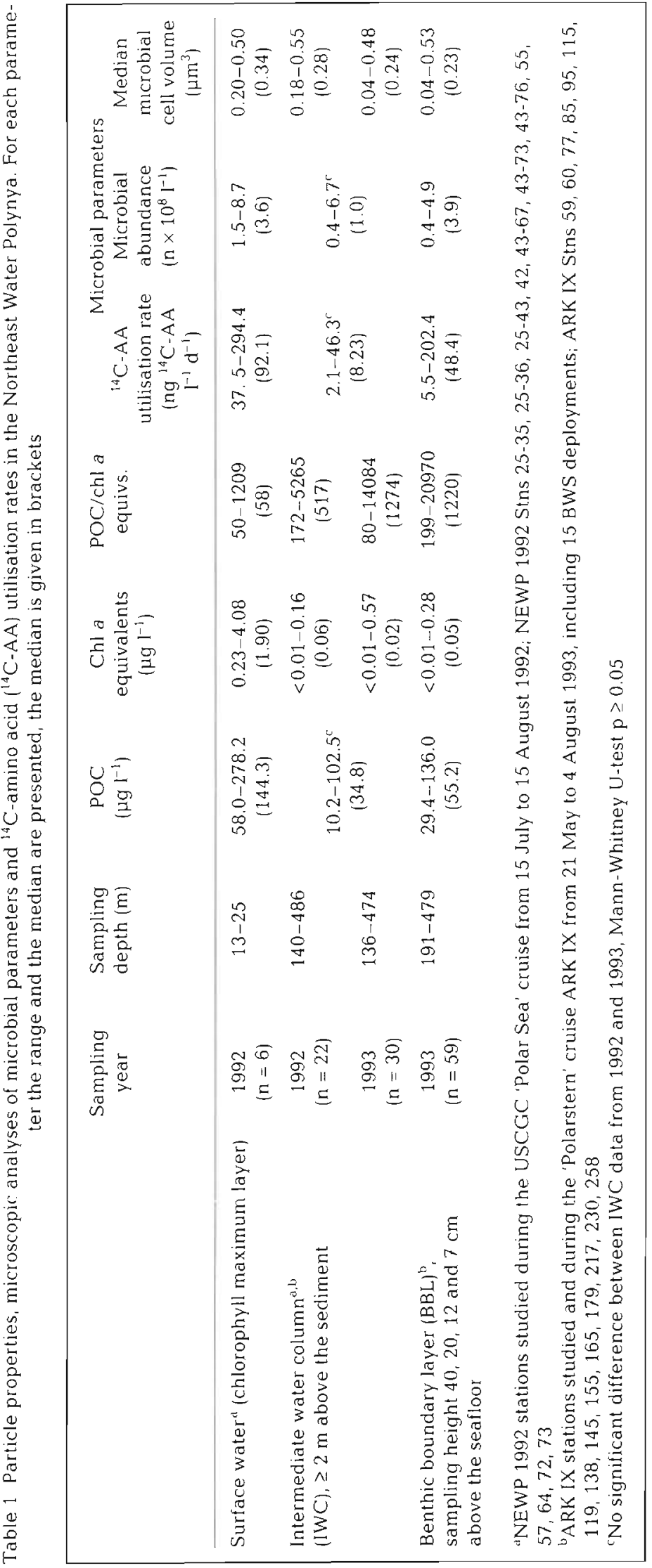

$\left(1.5 \times 10^{8}\right.$ to $8.7 \times 10^{8} \mathrm{l}^{-1}$ compared to $0.4 \times 10^{8}$ to $4.9 \times 10^{8} \mathrm{I}^{-1}$ in the $\mathrm{BBL}$ ) a similar range of ${ }^{14} \mathrm{C}$ amino acids utilisation rates was observed in the chlorophyll maximum layer and the BBL (Fig. 1). Using autoradiography, Meyer-Reil (1978) reports that in average $31 \%$ (range between 2.3 and $50.5 \%$ ) of individual cells within a microbial community are active. For various active fractions of the microbial community $(10,20,30$ or $100 \%)$, the normalised cell-specific utilisation rates of ${ }^{14} \mathrm{C}$-amino acids reached higher values in the BBL in $1993 \mathrm{com}$ pared to those observed in the surface waters in 1992 (Fig. 2). The median cell-specific ${ }^{14} \mathrm{C}$ amino acid utilisation rate of $0.1{ }^{14} \mathrm{C}$-amino acids cell ${ }^{-1} \mathrm{~d}^{-1}$, assuming all bacteria were active, was similar to the range of 0.04 to $0.46{ }^{3} \mathrm{H}$-glutamic acid cell ${ }^{-1} \mathrm{~d}^{-1}$ found in the bottom waters of the Santa Monica Basin (Craven \& Carlucci 1989). Furthermore, if there is a hypothetical constant cell-specific utilisation rate of $2 \mathrm{fg}{ }^{14} \mathrm{C}$-amino acids cell ${ }^{-1} \mathrm{~d}^{-1}$ (which amounts to about $2 \%$ of the $\mathrm{C}$-content of a bacterial cell) we calculated the fraction of the bacterial community which has to be active to account for the community utilisation rate. Accordingly ca $12 \%$ of the bacteria would have

Cell-specific activity [fg ${ }^{14} \mathrm{C}$-amino acids cell-1 $\mathrm{d}^{-1}$ ]

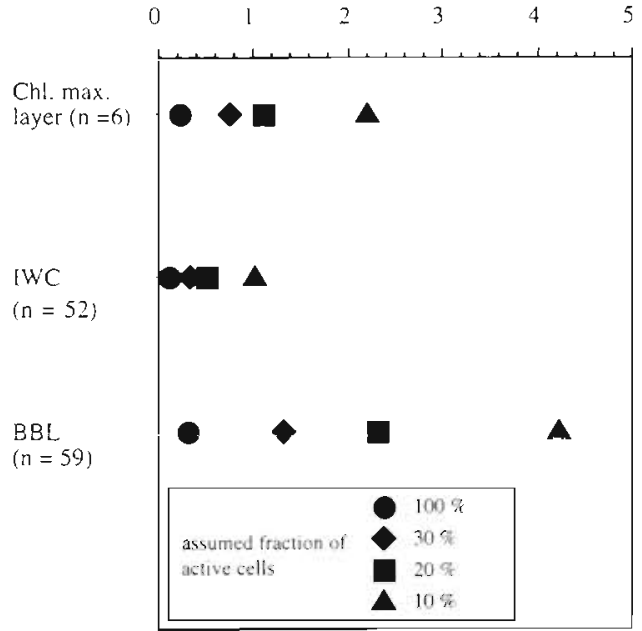

Fig. 2. Distributions of median cell-specific utilisation rate of ${ }^{14} \mathrm{C}$-amino acid in the chlorophyll maximum layer, the intermediate water column (IWC) and the benthic boundary layer (BBL). ${ }^{14} \mathrm{C}$-amino acid utilisation rates were normalized to bacterial abundances assuming $10,20,30$ and $100 \%$ active cells in the microbial community. The number of samples for each layer is given in parentheses 
been active (median, $\mathrm{n}=6$ ) in the chlorophyll maximum layer in 1992. Under the same assumption, in the IWC only $5 \%$ (median, $\mathrm{n}=52$ ) would have been active, whereas in the BBL $22 \%$ of the bacterial community would have utilised the offered substrate to account for the microbial activity measured there in 1993. However, it is most likely that the described significant differences in the microbial activity reflect the combined effects of the size of the active fraction and the stimulation level of individual cells within the bacterial community of each water layer.

Higher concentrations of POC per se cannot explain the stimulation of amino acid utilisation in the BBL compared to the IWC (Fig. 1). No significant correlation was observed between utilisation of ${ }^{14} \mathrm{C}$-amino acids by the microbial community and the concentration of POC (Kendall's $\tau ; p>0.2$ ). And although the organic material in the IWC contained relatively more phytogenic material, indicated by lower ratios of POC to chl a equivalents (80 to 14084), amino acid utilisation was significantly lower than in the BBL, where the 'freshness' of the particulate material appeared to be lower (POC to chl a equivalents ratio 199 to 20970). This may be an indication of the importance of dissolved organic matter for microbial nutrition. In a first attempt to investigate this matter, DFAA were measured at 1 selected station (ARK IX; Stn 95). There the concentrations of DFAA ranged between 12 and $55 \mathrm{nM}$ (1.7 to $9.3 \mu \mathrm{g} \mathrm{l}^{-1}$ ) and displayed highest values in the BBL at 20 and $40 \mathrm{~cm}$ above the seafloor (Fig. 3a). DFAA concentrations at $5 \mathrm{~m}$ above the bottom and in the $\mathrm{BBL}$ in the NEWP at Stn 95 were in the range 6.8 to $27.3 \mathrm{nM}$ ) reported for the bottom water 3 to $6 \mathrm{~m}$ above the seafloor in the Santa Monica Basin (Craven \& Carlucci 1989). Knowing the concentration of DFAA allowed the calculation of absolute amino acid utilisation rates for the samples of Stn 95. Most rapid amino acid utilisation rates were found 7 and $40 \mathrm{~cm}$ above the seafloor: 1.3 and $2.2 \mathrm{nmol}$ amino acids $\mathrm{l}^{-1} \mathrm{~d}^{-1}$, respectively. The slowest rate was observed at $12 \mathrm{~cm}$ above the bottom (Fig. 3b). The median amino acid turnover time of $45 \mathrm{~d}(\mathrm{n}=4)$ in the BBL was about 1.5 times shorter than at $5 \mathrm{~m}$ above the bottom ( $66 \mathrm{~d}$ ). However, these turnover times were still significantly slower than reported for shallow temperate waters of less than $1.5 \mathrm{~h}$ for alanine (Fuhrman \& Ferguson 1986) or about 48 and $56 \mathrm{~h}$ for the bottom waters in the Santa Monica Basin (Craven \& Carlucci 1989). Fuhrman (1987) describes close coupling between the release of DFAA by primary producers and their microbial incorporation. Even if DFAA are assumed to be bioavailable, their accessibility to the individual bacterium is strongly dependent on the background concentration and transport rate of DFAA to the cell surface. Thus if the close coupling is extended to the accessibility of
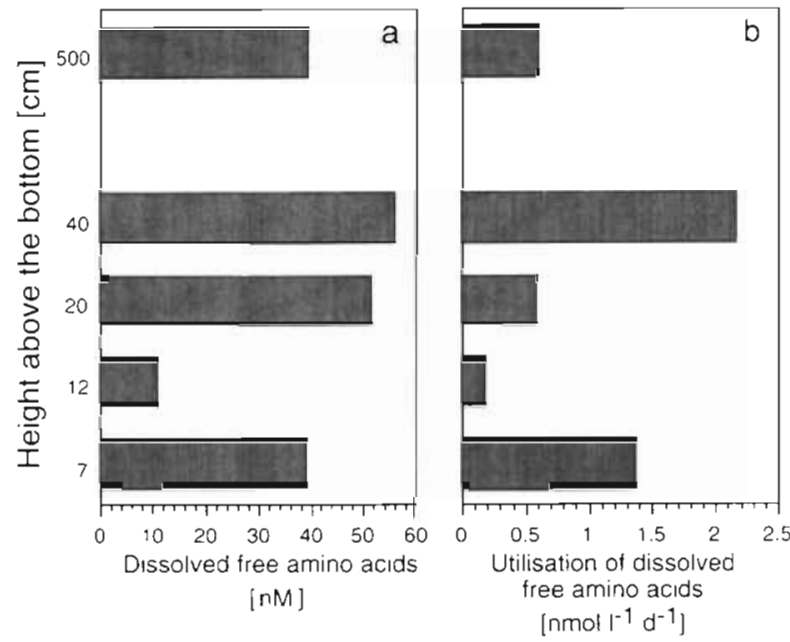

Fig. 3. Vertical distributions of (a) dissolved free amino acids (DFAA) and (b) absolute utilisation rates of DFAA at ARK IX Stn 95. DFAA were measured after OPA derivatisation according to Lindroth \& Mopper (1979)

DFAA to microorganisms, i.e. particle-associated bacteria in the BBL benefit from enhanced turbulent transport of DFAA towards the particle (see also next paragraph), the pattern of ${ }^{14} \mathrm{C}$-amino acid utilisation rates follows the distribution of DFAA in 3 out of 4 cases in the BBL. In contrast, the lower turbulence level above the BBL is not sufficient for the bacteria to access the potentially bioavailable amino acids (see below).

In the Santa Catalina Basin, Smith et al. (1987) report more than a doubling in concentrations of total dissolved amino acids from 50 to $1 \mathrm{~m}$ above the bottom. It can be argued that an increase of the background concentration of amino acids in the BBL, due to the enhanced activity of aminopeptidases produced by particle-associated bacteria (Smith et al. 1992), may lead to stronger isotope dilution closer to the seafloor than in the intermediate water column. A higher dilution of the ${ }^{14} \mathrm{C}$ substrates would result in underestimation of ${ }^{14} \mathrm{C}$-amino acid utilisation rates close to the seafloor. Thus, the significant difference in microbial activity between the BBL and the IWC may be even larger than measured such that a relative comparison between samples from the IWC and BBL, without any intention towards absolute amino acid utilisation rates, seems valid. And although the data base is small, the comparison of the absolute amino acid utilisation rates between the BBL and the IWC at Stn 95 supports this finding. Thus, the significantly higher microbial utilisation rates of ${ }^{14} \mathrm{C}$-amino acids, together with distinctly different particle properties, indicate that the BBL does indeed represent a uniquely different environment that favours bacterial activity.

However, the distribution and composition of particles and the concentration of labile organic matter as 
the possible food source for microorganisms cannot necessarily explain elevated activities in the $B B L_{i}$ alternative stimulatory processes have to be considered. In the following, the coupling of substrate concentration and microbial activity is discussed with respect to the accessibility of DFAA to microorganisms. ${ }^{14} \mathrm{C}$-amino acid utilisation rate at $7 \mathrm{~cm}$ was more than twice as high as at $5 \mathrm{~m}$ above the bottom (Fig. $3 \mathrm{~b}$ ), although the DFAA concentrations were similar in both cases ( 39.3 and $39.6 \mathrm{l}^{-1} \mathrm{~d}^{-1} \mathrm{nM}$, respectively). Therefore this distribution of utilisation rates could not be influenced by the concentrations of DFAA alone. The accessibility, i.e. a combination of DFAA concentration and transport of substrate towards the microorganisms, may be the key factor for the observed activity distribution pattern. Thus, detailed consideration of the hydrodynamical regime is essential for the evaluation of microbiological processes in the benthic boundary layer (Ritzrau 1996). Without going into details we will present how the theory of diffusive transport towards a particle under fluid shear could explain the distribution of microbial activities at Stn 95. Following the equations of Ritzrau (1996) and his parameterisations of diffusivity and kinematic viscosity, it is possible, given some assumptions, to calculate the diffusive transport rate of amino acids to a particle-associated bacterium. At Stn 95 at $16 \mathrm{~cm}$ above the seafloor the current velocity was $3.9 \mathrm{~cm} \mathrm{~s}^{-1}$. Using this value and assuming a roughness height of $0.1 \mathrm{~cm}$ the hydrodynamic regime can be defined. Subsequently shear rates, Sherwood numbers and diffusive fluxes of amino acids can be analysed. The Sherwood number is a dimensionless coefficient which describes the theoretical increase of diffusive transport due to fluid shear compared to the flux in a stagnant fluid. In the BBL the Sherwood numbers for a particle with a diameter of $200 \mu \mathrm{m}$ ranged between 3.9 and 3.1 between 7 and $40 \mathrm{~cm}$ above the seafloor, respectively. At $5 \mathrm{~m}$ above the seafloor this coefficient was only 2.4. Combining these values with known concentrations of amino acids of 39.3 and $39.6 \mathrm{nM}(7 \mathrm{~cm}$ and $5 \mathrm{~m}$ above the seafloor; Fig. 3a) and assuming that the particle-associated bacteria maintain a concentration gradient between the background concentration and the particle surface, the resulting diffusive flux would be 1.6 times higher at $7 \mathrm{~cm}$ than at $5 \mathrm{~m}$ above the seafloor, even though the amino acid concentrations were similar. Although based on very rough assumptions, these calculations suggest that the accessibility of amino acids estimated from transport rate rather than concentration alone may be a new approach to explain the distribution of microbial activities close to the seafloor. The particle diameter is an essential parameter for the determination of diffusive fluxes (Ritzrau 1996) and it is unlikely that the particle or aggregate size distribution in the
BBL and in the IWC was similar. Thus, besides information on the substrate concentrations and hydrodynamic regime, the near bed particle size distribution needs more consideration to validate the proposed approach.

Hydrodynamical sorting in the BBL can produce distinct vertical distributions of particles with distinguishable properties (Muschenheim 1987. Thomsen \& Graf 1995). Resuspension of marine sediments in laboratory flumes as well as in the field has been shown to increase bacterial abundance close to the seafloor (Wainright 1987, Ritzrau \& Graf 1992). Whether this finding was due to resuspension of larger benthic bacteria or due to microbial growth in suspension was not addressed in the 2 cases. Intensive hydrolytic activity of particulate polysaccharides (Smith et al. 1992) and exudation of low molecular weight compounds by particle-associated bacteria (Vandevivere \& Kirchman 1993) may release labile organic material into the surrounding water, propagating particle production by physico-chemical aggregation of dissolved organic and mineral compounds (Muschenheim et al. 1989). Jumars et al. (1989) proposed that the release of labile dissolved organic carbon (DOC), especially digestive enzymes and un-assimilated gut content from heterotrophic metazoan egestion, could close the microbial loop in the water column. These processes may release labile dissolved organic matter in the BBL and it is most likely that the turbulent hydrodynamic regime (Gust 1989) distributes the compounds rapidly within the BBL. Studies on the effects of fluid shear on microbial activity in the water column have shown that particle-attached bacteria benefit nutritionally over free-living forms (Logan \& Kirchman 1991) if the host particle is large enough ( $>100 \mu \mathrm{m}$ ) to overcome viscous constraints of nutrient fluxes (Jumars et al. 1993, Ritzrau 1996). Thus higher concentrations and turbulent transfer of nutrients to particle-associated bacteria, as calculated above, could explain the observed distribution patterns of microbial activity in the BBL, always assuming that the higher accessibility of labile organic compounds translates into elevated ${ }^{14} \mathrm{C}$ amino acid utilisation rates close to the seafloor.

Although we have only limited information on concentrations of amino acids, the differences in microbial activity between the water column and the BBL verifies our hypothesis that the modification of organic matter close to the seafloor can be as rapid as in the euphotic zone. One possible explanation is that the hydrodynamic regime of increasing turbulent stress towards the sediment (Gust 1989) stimulates the modification of organic material by most likely particleattached microorganisms close to the seafloor (Ritzrau 1996). By this process, the fate of POC is not only influenced by microbial modification, but bacterial produc- 
tion of POC serves as a supplementary food source for suspension feeding benthos organisms. Moreover the rate of modification of organic matter in the BBL can be as rapid as in the euphotic zone. Our data suggest that in contrast to the euphotic zone, where microorganisms mainly mediate the demineralisation of organic matter in the tightly coupled relationship between autotrophic and heterotrophic organisms, microbial processes in the BBL largely influence the modification of particles and transformation of dissolved organic matter. This not only has an impact on energy budgets for benthic communities, but may also alter organic substances in a way previously proposed only for deeper sediment layers (Freeman et al. 1990).

Acknowledgements. The authors thank the masters and crews of the USCGC 'Polar Sea' and RV 'Polarstern' for their assistance during the 1992 NEWP and the 1993 ARK IX cruises. We thank E. Suess, L.-A. Meyer-Reil, M. Köster, S. Pesant and 4 anonymous reviewers for helpful comments on the manuscript. This study was partly supported by the ARCSS program of the NSF as part of the International Polynya Project and by a NSF PYI grant to J. W. Deming and by the 'Deutsche Forschungsgemeinschaft' through the 'Sonderforschungbereich $313^{\prime}$ at the University of Kiel. This is publication no. 315 of the Sonderforschungsbereich 313 .

\section{LITERATURE CITED}

Alldredge AL, Passow U, Logan BE (1993) The abundance and significance of a class of large, transparent organic particles in the ocean. Deep Sea Res 40:1131-1140

Amon RMW, Benner R (1994) Rapid cycling of high-molecular dissolved organic matter in the ocean. Nature 369: $549-552$

Cho BC, Azam F (1988) Major role of bacteria in the biogeochemical fluxes in the ocean's interior. Nature 332: $441-443$

Cho BC, Azam F (1990) Biogeochemical signifjcance of bacteria biomass in the ocean's euphotic zone. Mar Ecol Prog Ser 63:253-259

Confer DR, Logan BE (1991) Increased bacterial uptake of macromolecular substrates with fluid shear Appl Environ Microbiol 57:3093-3100

Craven DB, Carlucci AF (1989) Spring and fall microheterotrophic utilization of free amino acıds in a Calıforma Borderland basin. Mar Ecol. Prog Ser 51:229-235

Deming JW, Yager PL (1992) Natural bacterial assemblages in deep sea sediments: towards a global view. In: Rowe CiT, Pariente $V$ (eds) Deep-sea food chains and the global carbon cycle. Kluwer Academic Publishers, Dordrecht, p $11-27$

Freeman KH, Hayes JM, Trendel JM, Albrecht P (1990) Evidence from carbon isotope measurement for diverse origins of sedimentary hydrocarbons. Nature 343:254-256

Fuhrman J (1987) Close coupling between release and uptake of dissolved free amino acids in sea water studied by an isotope dilution approach. Mar Ecol Prog Ser 37:45-52

Fuhrman JA, Ferguson RL (1986) Nanomolar concentrations and rapid turnover of dissolved free amino acids in seawater: agreement between chemical and microbiological measurements. Mar Ecol Prog Ser 33:237-242

Gust G (1989) The benthic boundary layer. In: Sündermann J (ed) Oceanography. Springer-Verlag, Berlin, p 345-398

Hobbie JE, Crawford CC (1969) Respiration corrections for bacterial uptake of dissolved organic compounds in natural waters. Limnol Oceanogr 14:528-532

Iriberri J, Unanue M, Barcina I, Egea L (1987) Seasonal variation of population density and heterotrophic activity of attached and free-lıving bacteria in coastal waters. Appl Environ Microbiol 53:2308-2314

Jumars PA, Deming JW, Hill PS, Karp-Boss L, Yager PL, Dade WB (1993) Constraints on marine osmotrophy in an optimal foraging context. Mar Microb Food Webs 7(2):121-159

Jumars PA, Penry DL, Baross JA, Perry MJ, Frost BW (1989) Closing the microbial loop: dissolved carbon pathway to heterotrophic bacteria from incomplete ingestion, digestion and absorption in animals. Deep Sea Res 36:483-495

Karl DM, Knauer GA, Martin JH (1988) Downward flux of particulate organic matter in the ocean: a particle decomposition paradox. Nature 332:438-441

Karl DM, Knauer GA, Martin JH, Ward BB (1984) Bacterial chemoautotrophy in the ocean is associated with sinking particles. Nature 309:54-56

Karl DM, Tilbrook BD (1994) Production and transport of methane in oceanic particulate organic matter Nature 368:732-733

Kirchman DL, Suzuki Y, Garside C, Ducklow HW (1991) High turnover rates of dissolved organic carbon during a spring phytoplankton bloom. Nature 352:612-614

Lindroth P, Mopper K (1979) High performance liquid chromatography determination of subpicomole amounts of amino acids by precolumn fluorescence derivatization with o-phthaldialdehyde. Analyt Chem 51:1667-1674

Logan BE, Kirchman DL (1991) Uptake of dissolved organics by marine bacteria as a function of fluid motion. Mar Biol $111: 175-181$

Lorenzen CJ (1967) Determination of chlorophyll and phaeopigments: spectrophotometric equations Limnol Oceanogr 12:343-346

Meyer-Reil LA (1978) Uptake of glucose by bacteria in the sediment. Mar Biol 44:293-298

Muschenheim DK (1987) The dynamics of near-bed seston flux and suspension feeding benthos. J Mar Res 45: $473-496$

Muschenheim DK, Kepkay PE, Kranck K (1989) Microbial growth in turbulent suspension and its relation to marine aggregate formation. Neth J Sea Res 23:283-292

NEWATER-Investigators (1993) Northeast Water Polynya Polar Sea cruise results. EOS Trans Am Geophys Union 74:343-346

Palumbo AV, Ferguson RL, Rublee PA (1984) Size of suspended bacterial cells and association of heterotrophic activity with size fractions of particles in estuarine and coastal waters. Appl Environ Microbiol 48:157-164

Porter KG, Feig YS (1980) The use of DAPI for identifying and counting aquatic microflora. Limnol Oceanogr 25:943-948

Ritzrau W (1996) Microbial activity in the benthic boundary layer (BBL): small scale distribution and its relationship to the hydrodynamic regime. J Sea Res 36:171-180

Ritzrau W (1997) Pelagic microbial activity in the Northeast Water Polynya, summer 1992. Polar Biol 17:259-268

Ritzrau W. Graf G (1992) Increase of microbial biomass in the benthic turbidity zone of Kiel Bight, Baltic Sea, after resuspension by a storm event. Limnol Oceanogr 37:1081-1086

Ritzrau W, Thomsen (1997) Spatial distribution of particle composition and microbial activity in the benthic boundary layer (BBL) of the Northeast Water Polynya. J Mar Syst 10:415-428

Smith DC. Simon M, Alldredge AL, Azam F (1992) Intense hy- 
drolytic enzyme activity on marine aggregates and implication for rapid particle dissolution. Nature 359:139-142

Smith KL Jr, Carlucci FA, Jahnke RA, Craven DB (1987) Organic carbon mineralization in the Santa Catalina Basin: benthic boundary layer metabolism. Deep Sea Res 34:185-211

Sokal RR, Rohlf JF (1981) Biometry. WH Freeman and Company, New York

Thomsen L (1991) Treatment and splitting of samples for bacteria and meiofauna biomass determinations by means of semiautomatic image analysis system. Mar Ecol Prog Ser 71:301-306

This article was presented by Lutz-Arend Meyer-Reil, Kloster/Hiddensee, Germany
Thomsen L, Graf G (1995) Benthic boundary layer characteristics of the continental margin of the western Barents Sea Oceanol Acta 6:597-607

Thomsen L, Graf G, Martens V, Steen E (1994) An instrument for sampling water from the bottom nepheloid layer. Cont Shelf Res 14:871-882

Vandevivere P, Kirchman DL (1993) Attachment stimulates exopolysaccharide synthesis by a bacterium. Appl Environ Microbiol 59:3280-3286

Wainright SC (1987) Stimulation of heterotrophic microplankton production by resuspended marine sediment. Science 238:1710-1711

Manuscript received: November 12, 1996

Revised version accepted: July 22, 1997 